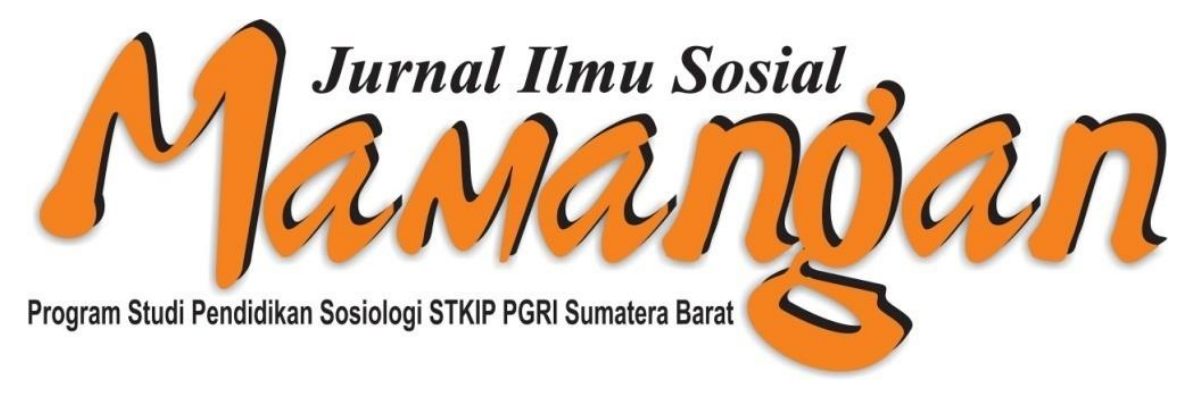

Jurnal Ilmu Sosial Mamangan

Volume 9, Nomor 1, Bulan January-June, 2020

\title{
TITLE OF ARTICLE
}

$\begin{array}{ll}\text { Author (s) } & \text { : Jarudin, Salma } \\ \text { Source } & \text { : Jurnal Ilmu Sosial Mamangan, Volume 09, Issue 1, January-Juny, } 2020 \\ \text { Publisher } & \text { : LaboratoriumPendidikanSosiologi, STKIP PGRI Sumatera Barat }\end{array}$

\section{To Cite This Article:}

Jarudin, Salma(s), 2020. Sumbayang Ampek Puluah As A Media Of Religious emansipation Of Women Workers In Sijunjung

Jurnal Ilmu Sosial Mamangan, Volume 9, Issue 1, January-June , 2020: 48-59.

Copyright (C) 2020, Jurnal Ilmu Sosial Mamangan

ISSN: 2301-8496 (Print) \& 2503-1570 (Online) 


\title{
SUMBAYANG AMPEK PULUAH AS A MEDIA OF RELIGIOUS EMANSIPATION OF WOMEN WORKERS IN SIJUNJUNG
}

\author{
Jarudin $^{1}$, Salma ${ }^{2}$ \\ 1STKIP PGRI Sumatera Barat \\ Email: jarudin200407@gmail.com \\ 2Universitas Islam Negeri Imam Bonjol Padang \\ Email:salma@uinib.ac.id
}

\begin{abstract}
This research analyzed the activities and understanding of Muslim women in the Sijunjung area accompanying Ramadan fasting in Sumbahyang Ampek Puluh activities. This religious activity was held in forty days throughout Ramadan Month where 10 days conducted before Ramadhan Month and 30 days in Ramadhan Month. Data were conducted toward observation of Sumbahyang Ampek Puluh activities in 7 Mosques in Sijunjung region during Ramadan Month in 2018 and interviews with several preachers and women of Sumbahyang Ampek Puluh members. Qualitative data analysis was conducted descriptively towards reduction, display and verification. The results show that Sumbahyang Ampek Puluh is dominantly followed by women. These women are at the age of menopause but economically it is still very productive. During the day they work in the fields, gardens, stalls and at night, they stay in the mosque to pray in congregation, pick up the congregational prayers that are left behind, read and study the Qur'an, study Fiqh, interpret the Qur'an and the problems of monotheism, never leave the prayer in congregation, stay away from immoral acts and try to get closer (taqarrub) to Allah like men.
\end{abstract}

\section{Keywords: Islamic Law, Worship, Women, Ramadan, Sumbahyang Ampek Puluh}

\section{INTRODUCTION}

Ramadan is a very special Hijri month for Muslims. Muslims around the world carry out fasting for one month during this month. In many hadiths it is explained that fasting is usually accompanied by other worship with far more good. In Qur'an, many things are explained about the equality of male and female degrees. This is more prominent when al-Qur'an is translated by reformists (Iwanebel, 2013). Many ways can be done by women to get and improve quality of education, knowledge and piety such as conducting worship activities in certain groups or communities. For example, the women's community in Sumbahyang Ampek Puluh in Sijunjung Region followed by Muslims. In this region, Ramadan month is the expected month for conducting the Sumbahyang Ampek Puluh.

This forty prayer is not Suluk and is very different from Suluk carried out by other groups in this community such as staying for a long time in the mosque, mosquito nets, restricting certain foods and drinks and not 
going home for a certain time. Meanwhile, Sumbahyang Ampek Puluh is carried out in mosques, mushalla or surau in every Nagari in a different way. The subject matter given by the group leaders varies from issues of fiqh (Islamic law), aqeedah, morals and Sufism. Middle-aged women who work in this region have the freedom to increase their knowledge informally in Ramadan, even though on a daily basis they have other responsibilities as breadwinners and household care.

In a more practical context, this ideal condition is not always obtained by women in other regions. Sechzer (2004) illustrates that the status of Islamic women varies in Muslim countries and depends on different interpretations of religion and Islamic law (preacher) in these countries. Most of these Islamic countries or countries with Muslim populations have special views about women and have restrictions on them. The gender stereotypes of Islamic women stem is from the evolution of the Islamic religion. In some countries, demands for women's freedom and laws are passed to improve their conditions. Islamic woman's group continue their struggle to reclaim their rights guaranteed in Qur'an and Sunnah including the right to increase religious knowledge and practice at the same time. Katz's study (2008) in Yemen on women who are often given less access to mosque-based piety rituals. Women are destined to be marginalized in male-dominated Islamic education and normative construction. The piety of women in Malaysia was measured by Kool (2008) from three categories, namely the use of veils in various situations, the willingness to become a second, third and fourth wife (polygamy) and the willingness to adopt foster children but not from the point of religious education. In Sulaiman's study, Quayum (2018) in America and Safitri (2010) in France that wearing the Hijab included in the education area is a very difficult struggle for some Muslim women in some areas because wearing hijab becomes their identity as a devout Muslim in the foreign country. In a further context, Ibrahim (2014) and Umar (2007) in Nigeria, women have limitations to carry out other social activities such as education, politics, law and government.

$$
\text { Wahib's (2017) in Indonesia }
$$
shows that the limitations of women are depicted in the Salafi community. Women must wear the hijab (veil) which characterizes their piety and it is also not measured by their religious education. Widiastuti (2017) argues that the lack of education and religious knowledge makes women retarded and vulnerable to conflict. Likewise in the findings of Beta (2016), Ansor (2014) and Armiah (2004) that Muslim clothing is a symbol of piety. Specifically for Javanese women, Widyastuti (2014) suggested that there was a gender imbalance in serat suluk residriya including subordination, stereotypes of women, may use but may not have, women as sexual objects, and polygamy, also in books as educational products ( Rasyidah, 2009), (Nurwanto, 2012), (Marhumah, 2015) and also in legal products (Fanani, 2017). Likewise, Mukodi's (2015) findings about the Samin women's community in Blora are still placed as male sub-ordinates. Among other things caused by the low level of education trigger the weak involvement of Samin women in public. However, in certain groups of women, education does not necessarily make them think forward but step back into fundamentalism (Ulfah, 2014). Seeing the various gaps, there have been efforts by many parties both individually (Widiyanto, 2014), (Harpci, 2015), (Ismail, 2017), (Rahman, 2017), and institutionally (Ridho, 2010) to fight for women's rights. Based on the description above, this article aims to analyze and describe Sumbayang Ampek Puluah as a medium for religious emancipation of working women in Sijunjung.

\section{RESEARCH METHODS}

This type of research was located in Sijunjung Regency, West Sumatra Province. Sumbahyang Ampek Puluh is generally held in many mosques, mushalla or surau in Sijunjung Regency, so that conditions distinguish them from other regions in West Sumatra. Based on that, the researcher chose 7 locations as research objects. The data used consisted of primary and secondary data. Data collection were collected by observation, interview and study documentation. Researchers had observed Sumbahyang Ampek Puluh during Ramadan in 2018 of 7 mosques in Sijunjung. There were 
109 women who took part in the prayer activities in seven places. Researchers collected adequate data through in-depth interviews with people who are considered important to provide information about the tradition of Sumbahyang Ampek Puluh namely some Sumbahyang Ampek Puluh group priests, women participating in Sumbahyang Ampek Puluh and some of their family members who are not participating in the activities. All of these interview data were described in the results of the study by not mentioning informants one by one because of the large number of those interviewed. Data were collected towards observation, interviews and documentation processed and described. According to Miles \&Hubermen (1992), data were analyzed towards data reduction, display and verification (drawing conclusions).

Researchers conducted observations, in-depth interviews and documented 7 mosques performed Sumbahyang Ampek Puluh during Ramadan in Sijunjung 2018. The places were Al-Muhajirin Mosque in Nagari Palaluar, Musalla Nurul Hidayah in Nagari Pematang Panjang, Musalla Sheikh Amiluddin in Nagari Sijunjung, and Surau Loban Twist in Nagari Sijunjung, Tuau Kuniang Surau in Nagari Tanjuang Bonai, Baruah Bawah Mosque in Sumpu and Surau Twist Loban in Nagari Sijunjung, Surau Tuangku Kuniang in Nagari Tanjuang Bonai, Masjid Baruah Bawah in Sumpu and Surau Lenggek in Nagari Kumani. There were 109 women in the seven prayer groups from seven locations. As for their educational backgrounds, they are quite varied. Generally, they had completed high school and junior high school education. There were also some people who had completed diploma and Bachelor-level education. Even so, there were also those who only graduated from elementary school and there were even some people who did not complete primary school, but they were able to read and write the Qur'an and Arabic Malay but not Latin.

\section{RESULT AND DISCUSSION}

\section{Profile of Sijunjung Regency}

Sijunjung Regency is one of the second level regions in West Sumatra Province. According to Tambo, Sijunjung Regency has already known civilization since the 10th century $A D$ because in this region, there was a Kingdom of Guava Lipo. This kingdom existed before the Minangkabau Kingdom in Pagaruyung. After the proclamation of independence, in October 1945, Tanah Datar District was formed where the capital city was Sawahlunto. This regency covers Batusangkar, Padang Panjang, Solok, Sawahlunto and Sawahlunto / Sijunjung. Along with the development of governance, each of these regions had already established and finally constructed into one district or city, including Sijunjung Regency (Thaib, 2012). Sijunjung is inhabited by the Minangkabau Muslim community, so it is not surprising that mosques are very easy to find and not too far away. For the people of Sijunjung, the mosques do not only function as a place for praying but it is also used for other social activities such as education, traditional deliberations, khatam al-Qur'an, celebrating of the Prophet's Birthday and others. Basically Aljunied (2018) finds that the function of mosques in Indonesia is the same, namely for the center of business, education and other social activities.

Sumbahyang Ampek Puluh is a tradition of Islamic followers of Naqsabandiyah. This tradition is conducted 10 days before Ramadan and 30 days of Ramadan. People bring food and sleep equipment for 40 days. During the process, the community will carry out a process of worship reading the Koran, praying, and other religious activities. By carrying out this activity, it will make the follower to be closer to God and can carry out religious activities in a timely manner.

Sumbahyang Ampek Puluh is not held in all mosques but it is only held in several mosques in Sijunjung. In the Profile of Sijunjung Regency, it is stated that there are more than 90 mosques in this area, although it is not all of them are documented. One thing is clearly that where each Jorong has one or more than a mosque. In another word, there are up to 6 mosques in each Nagari 
holds Sumbahyang Ampek Puluh which are attended by women.

\section{Sumbahyang Ampek Puluh as Emancipation of Religion}

\section{a. Working in the Day}

Each group of Sumbahyang Ampek Puluh women prayers in 7 mosques ages between 15 and 20 years ol, although in some groups also finds some male worshipers as many as 1-5 people including the imam, but generally this group consists of women. They are over 45 years old and do not experience for menstruation anymore (menopause). They say, if women still get menstruation every month, then the situation will break the congregational prayer for 40 days as the main characteristic of this Sumbahyang Ampek Puluh community. In their understanding, if a woman is committed to being a member of the Sumbahyang Ampek Puluh group, then she must pledge herself to never leave the congregational prayer even though it is an obligatory paying. This belief is obtained from the hadith that their Imams has explained.

\section{b. Working in the Day and Night}

Generally, in a group of Sumbahyang Ampek Puluh, the women are good workers working in rubber fields, rice fields, cattle herding and some are working as traders. After Subuhcongregational praying, they read the Koran in a short time (until the morning light began to appear). Then, they go home and work in their fields until nearing the noon time. If their working place is close to the mosque, then they take the time to attend the congregational praying. But many of them work far from the location of SumbahyangAmpekPuluh, so they are forced to pray alone at their place of work and repeat their prayers in congregation in the mosque at night after the evening prayingwith the Imam and Sumbahyang Ampek Puluh members .

Indeed, there were also some of these women who do not work but they were quite old and could no longer work in the fields / gardens. Even so, they are still able and take the time to take care of and clean up their home environment. Therefore, these women show their qualities as real women who make money, use time efficiently in the daytime to meet the daily needs of families and worship to the maximum to draw closer to God at night. Not only that, they also make sure their family members are not neglected. Usually, in the afternoon, after the Asyar praying, they prepare food for dawn and breaking their fast at the same time for their provisions while staying in the mosque. From 109 women who participate inSumbahyang Ampek Puluh, 29 of them do not work in the economic sector of producing money. Even so, they still help take care of their household, especially, they are able to take care of themselves and do not depend on others.

There are some of Praying forms conducted by the prayers both day and night:

\section{1) Fasting in the Daylight}

Fasting is the main activity carried out by Sumbahyang Ampek Puluh. There are at least three ways for them to conduct SumbahyangAmpekPuluh, first, they start 10 days before Ramadan, then fasting for 10 days is called fasting in the month of Sya'ban and then followed by fasting for a month in Ramadan. Regardless of the number of days of Ramadan between 29-30 days but this group ensures that their fasting is as much as 40 days. Sumbahyang Ampek Puluh is closed on the 1st of Syawal or on Eid al-Fitr. Therefore, they sufficiently circumcise fasting on 10 days Syakban complete with prayer in congregation. Second, if they start this forty prayer on the 1st of Ramadan, then they fast for 29-30 days in the month of Ramadan and add 10 more days besides 1 Shawwal in the month of Shawwal. Usually, they feast on the 10 th or 11th day of Syawal. Thus, they provide a 10-day fast in Shawwal, except on the 1st of Shawwal and their congregational prayers. Third, if they start the five-day fast at the end of the Sya'ban month and finish the fortieth day at five (6-7) days, at the beginning of the month of Shawwal (other than 1 Syawal). They say that fasting for 5 days in the month of Sha'ban is based on fasting carried out by the Prophet Muhammad, and likewise, fasting for 6 days in the month of Shawwal based on the actions of the Prophet. They call this fasting is PuasoAnam (six-day fasting).

Sumbahyang Ampek Puluh prayer groups understand that Ramadan is a very special month for Muslims. As they learn 
from Imam of Sumbahyang Ampek Puluh that in Ramadhan month the merit of all good is multiplied both the goodness of the obligatory practices and the practices of circumcision. Researchers find out about the reasons or le gal basis for fasting before and after Ramadan they do. These women generally say that the Imam who leads them is more wise and understands the basis of the implementation of fasting both in the Sya'ban month and in the Syawal month after IdulFitri. In this case, they only believe that the worship that they perform is explained or ordered in the Qur'an and Sunnah, even though they could not able to show it both speaking and writing. This is different when the Imam gives an explanation. The Imams who generally know and understand the reasons or theorems supporting the implementation of this activity. Some of them even show the position of their propositions in one book. According to them, the argument about the fasting of Ramadan and the values of worship contained in it is a proposition that has been proven (widely known) and is easily found both in the books of fiqh and in Indonesian language books. The fasting before the month of Ramadan is based on the hadith of the Messenger of Allah s.a.w. about the actions of the Prophet fasting in the month of Sha'ban. Likewise, it is the basis for fasting in Syawal. This is known and explained by the priest by using the Shafi'iyah standard schools in the mosque where Sumbahyang Ampek Puluh is held.

\section{2) Obligatory Congregational Praying and Sunnah Praying}

Sumbahyang Ampek Puluh groups which is carried out in congregational praying is divided into two categories. First, regular congregational praying which is called obligatory praying (Fajr, Zuhr, Asyar, Maghrib and Isha). Secondly, i'adah praying is a group member who performs the obligatory prayers alone during the day in places where they work both in the fields, fields etc.), then they repeat the prayers that they do alone in congregation at night. In their understanding, when praying in congregation is left behind, even though it is an obligatory praying, then Sumbahyang Ampek Puluh is considered invalid. However, if during the day they do not have time to pray in congregation, then in the evening, the Imam of the group will guide them to pick up the congregational prayer by repeating the congregational prayer for the times left such as the Zuhr and Asyar praying that they do in the fields / gardens. In the context of Jurisprudence (Islamic law), this method of prayer is called i'adah praying. Imam of Sumbahyang Ampek Puluh group explains that $i^{\prime} a d a h$ praying is legal. He expresses his opinion based on the traditions of the Prophet s.a.w. which tells about the Prophet and the Companions who repeat the praying when an event occurs. Among these traditions, it can be found in the Sahih alBukhariy Book. In this hadith, the story of MuazibnJabal is explained as the Imam of the Isha praying. He reads al-Baqarahin the praying. It is s complained by one of the Companions who had other interests to hurry up, so he broke away and repeated his prayer alone. Responding to this, the Prophet s.a.w sniffed Muaz and reminded him to consider the benefits when choosing surah to read in praying. This hadith becomes one of the bases used by the Imam of Sumbahyang Ampek Puluh group to perform the i'adah praying for women who do not have time to pray in congregation when they joined into Sumbahyang Ampek Puluh.

In addition, to carrying out the obligatory praying in congregation, they also complement Ramadan with qiyamullail such as Taraweh praying, reading and studying the Qur'an, collecting various types of Sadaqah (Sadaqah for personal and for close family such as father, mother, grandfather, grandmother usually the group member asks the Imam to pray for the person he gives alms on behalf of), Zakat and donations for orphans. They also reproduce and complete the circumcision praying that they rarely do on ordinary days outside of Ramadan such as Rawatib circumcision praying. They believe that in the month of Ramadan, the actions of circumcision, especially the practice of circumcision, is multiplied by the reward and the value of goodness, even, according to them, the reward is far more than the compulsory worship carried out on ordinary days

\section{3) Reading and TahsinAlquran}

Each member of the Sumbahyang Ampek Puluh group has already had a 
commitment to complete the reading of the Qur'an during the implementation of the activity. They are generally able to explain that al-Qur'an is first revealed in Ramadan (QS al-Baqarah (2): 185) and in the first verse it is ordered to read (QS al-'Alaq (96): 1-5). They also mention that in the hadith, many things are stated about the virtues of the month of Ramadan and the value of worship for those who do it. The postulates of this law are instilled in such a way by the Imam to the members of the group of Sumbahyang Ampek Puluh, so that understanding raises to the belief that these Sumbahyang Ampek Puluh could give more value to themselves and could also accomplish as much rewards as possible during Ramadan. Many of those who study the Qur'an, read it at the same time accompanying the reading with the translation, but many of them also only read the Qur'an without reading the translation. Researchers also finds that some Sumbahyang Ampek Puluh women who are able to read the Qur'an but they could not read their translations in Latin. Strangely, they are able to read Malay Arabic letters. Generally, women with this unique ability are elderly and have only received an ancient education using Arabic Malay letters.

Many women finish reading the Qur'an more than once then they deepen the meaning. This is very possible because they always use every spare time to read the Koran and especially after the Taraweh praying until midnight before they prepare to sleep and after the delivery of learning material at dawn until sunrise in the morning. Sometimes, they read the Koran together and take turns (tadajib), listen to and correct the Imam of the wrong reading but many of them also read and study the Koran independently. When there is one woman who has just finished reading the Koran (khatam), then the Imam hold a recitation session and lead the praying to finish reading the Koran. Generally, the prayings said by the Imam are the same and have been written in the back pages of the Qur'an. Sometimes, it is found that Imam recitation much longer.

\section{4) Studying the alquran Interpretation}

Delivering of learning material is usually conducted after the 'Isha praying before the Taraweh prayingand after the Subuhpraying. The Imam has prepared a learning schedule (semi-official) to fill in the activities of Sumbahyang Ampek Puluh such as learning the interpretation of the Qur'an, the knowledge of monotheism and and other religious studies. In some of Sumbahyang Ampek Puluh places, several commentaries are taught and studied bymember of gorupsuch as Tafsir Al-Azhar (Hamka), Tafsir al-Maraghiy and Tafsir Ibn Kathir. The interpretation material studied is mostly on the interpretation of the legal verses and verses related to the Knowledge of Tawheed. The commentary material taught by Imam of Sumbahyang Ampek Puluh is uncertain and not systematically-scheduled. This interpretation lesson is only left to the Imam's choice, although sometimes the Imam asks the group member what interpretation material to study). During the study, it is found some commentary material are studied during the Sumbahyang Ampek Puluh activities in Sijunjung such as material about 20 attributes of God, repentance, spirit, heaven, hell, fasting, ablution, tayammum, zakat, morals of the Prophet, fadhilah (goodness) deeds of worship, stories the story of several Prophets and many other materials

\section{5) Studying the Religion}

All members of the Sumbahyang Ampek Puluh are also given the learning of various branches of religious knowledge such as Fiqh, Tawheed and Sufism. In the notes of the Sumbahyang Ampek Puluh group members, it is found the learning materials above. Each group member gets a different character and learning method based on to the way each Imam. Even so, the substance and content of learning materials do not differ between one mosque to another. The Fiqh that they learn is about the pillars of ablution and praying. The pillars of ablution and prayingare learned based on the Shafi'iyah concept. as found in the book of Sumbahyang Ampek Puluh group members at Nurul Hidayah in Nagari Pematang Panjang below:

Pillar 13. Go to the first praying. We walk away to pray. A number of steps have already been calculated. A 
charity will not disappear. A number of steps has already been calculated. In the afterlife, it will be weighed. Then take a bath in the sea too. The deeds have been weighed. Light the way to heaven. After that wash your hands ... After that wash your feet. Azan first then ikamat. See you with the Prophet, See the form of the Prophet Muhammad.

The words contain about the order and procedure for ablution which is written in the verses of the song. Each stanza consists of four lines. These material verses do not only contain the pillars of ablution but also consist of the circumcision of ablution and its merit values. For example in the stanza which contains the way to rinse his mouth, then the next line contains the value of his goodness that is detached from the grave doom. This lesson is taught by singing / humming. Initially, this material was echoed by the Imam then it was followed together by group members. Sometimes, the Imam shows the practice or is directly exhibited. Likewise, when it is describing the pillars of prayer. In the same notebook written:

Preliminary Takbir of praying. Prayer's intention is included. Up to the shadows. The second is straightening up. The third pillar is takbir. It's already true. Already well-tempered ... Twelve greetings.Thirteenth orderly. Views change in nature ...

This stanza reveals that the intention to establish prayer is done simultaneously with Takbir. It shows that the intention taught by the Imam is part of the prayer pillars as taught in the Shafi'iyah school and distinguishes them from the 6 pillars of the Hanafiah sect and Malikiah with 14 pillars. In this stanza, it is also taught about the concept of human as a servant of God who is created to submit and serve Him. For example, it is found on the expression of inner zahir too. In another verse about bowing, it is found expressing a viewpoint on God. Eliminating all nature is merely form of submission to God. In the entire strophe, it is depicted about the prayingof a Muslim who is very dedicated 'and his body and soul are really directed only to the God he worships. This argument can be proven by the expression in the last lines, namely twelve giving greetings, changing views on nature as the meaning of the completion of prayer, the form facing God, then moving back to natural / worldly affairs.

The study of fiqh in Sumbahyang Ampek Puluh group at Al-Muhajirin Mosque in Nagari Palaluar is somewhat different from other groups. The subject of fiqh is not written in the form of stanzas but it is narrated in the form of a story that begins with the word baramulo (begins with) as follows:

Begin with that must be known from the pillars of prayer 13. first is intention, second is standing properly, third is takbirratulihram, fourth is you read patiha, fifth is bowing ...third is I'tidal ..., thirteen is orderly.

The fiqh material taught during Sumbahyang Ampek Puluh is quite diverse. The material is not only about ablution (pillars, circumcision ablution and the benefits of ablution), praying (starting from the call to prayer, iqamah, prayer harmony, circumcision prayers, the benefits and wisdom of prayer and things that cancel prayer) and fasting, procedures organizing bodies only but also learning about basic materials of ushul fiqh such as learning about the laws of Taklifi(ahkam al-taklifi) and the laws of wadh'i (ahkam al-wadh'iy).

Sumbahyang Ampek Puluh are also taught about the subject of monotheism. In general, they learn about the attributes of God and their meanings. In the notes of some members of group, the following materials are found:

Begin with the first thing must be known that is six things.

1. Knowing what obligatory for God is twenty

2. Knowing what impossible for God is the opposite of twenty

3. Knowing what good for God is making all the worlds

4. Knowing what obligatory for the Prophet is siddiq meaning true, tablig means conveying, amanah means place of trust, fathanah means smart / clever

5. Knowing what impossible for the Prophet is kizzib which means lying, kitman means hiding, betraying means unbelievable and baladu means stupid. 
6. Knowing what good for the Prophet such as 'arad basyariyah (sick, injured, killed), eating, drinking and others.

In this further note, it is found a more complete and clear explanation of the Imam. For example: Imam explains that the obligation is divided into three parts, the first is obligatory on sharak, which was compulsory in the context of fiqh. The word obligatory in the context of fiqh means what is rewarded when it is done and sinful when it is left. Second, it is obligatory on custom. When explaining this material, the group's Imam describes his intentions in the form of the proverb that is burning fire, cutting sakin (knife), water soaking and rice filling. It can be concluded that the Imam seeks to explain everything that is obligatory or must be in natural law. Third, it is compulsory for reason, that is, what is not reflected in the sense of its absence but it is there. The priest also explain the meaning of impossible, that is, which is not reflected in reason but it does not exist. Likewise, when he explains about jaiz from two points of view. First, jaiz on sharak is something that is not rewarded when working on it and it is not a sin when leaving it. In this case, Imam explains the meaning of jaiz in the context of fiqh. Second, jaiz on reason, that is, what is valid on reason, both the presence and absence.

There are other learning materials that are also related to Tawheed Science, namely about repentance. According to the Imam and members of Sumbahyang Ampek Puluh, repentance is one of the main important acts during Ramadan. They believe that Allah must forgive the sins of those who repent, especially during the month of Ramadan. In their study, material found about the elements of the body who repented when they uttered the phrase istighfar to Allah. First, the eye when looking at things results in sin by saying the sentence "I ask God for forgiveness in every sin of my two eyes". Second, the ears when I hear things that cause sin by saying "I ask about God to forgive me for every sin of both my ears. Third, the tongue when saying the words that causes sin by saying I ask forgiveness from God for every sin of my tongue. Fourth, hands when doing things that cause sin by saying "I ask God to forgive me for every sin of my hands". Fifth, feet when taking steps that result in sin by saying I ask forgiveness from God on every sin of both my feet. Sixth, the heart when it implies things that lead to sin by saying "I ask forgiveness from God for every sin strokes my heart. Seventh, all other members of the body when all members of the body move to do actions that result in sin by saying "I ask God to forgive every sin of my whole body".

In the repentance learning materials, it is understood that the Imam teaches about the substance of repentance that must be done by a Muslim. These women understand that the repentance taught by this Imam is easier to understand and to implement. This understanding arises because, in addition to the Imam's explanation, it is also based on the study of interpretations including Surah Yasin (QS. 36: 25) concerning the demands of responsibility for the actions of members of the body (especially the hands and feet). The repentance taught by the Imam is far more detailed than the repentance in the concept of fiqh. In fiqh, it is explained that repentance has at least some elements saying the phrase istighfar (asking forgiveness), promising and being serious about not repeating sins and accompanying repentance with good deeds.

Women workers in Sijunjung utilize the moment of Ramadan to increase knowledge and also the practice of their religion even though they have many limitations. The results of this study are in line with previous researchers such as Hidayati (2009) who suggested the existence of a conspiracy in Madura as a place of learning and worship for marginalized women, Jannah (2011) who stated about increasing the spiritual productivity of women, Rofhani (2017) who put forward about women's willingness to increase religious knowledge, Ardiyani (2017) who asserted that a Muslim woman does not only know and understand household matters but must also play a role in other religious and social affairs, Isnaini (2016) and Ismail (2017) who find the reality of freedom this is in the thought of ulama in West Sumatra in interpreting verses about women in the Minangkabau context. But the results of this study are different from the results of other studies. Sila (2009) suggests a similar activity followed by young people and educated 
people, Munir (2016), Taufiq (2017) who suggests a similar type of education but lasts a lifetime, Roza (2017) which describes similar activities but it is followed by men. Hanani (2016) explains that the contribution of Sumbahyang Ampek Puluh was initially followed by men who were old and not working.

Sumbahyang Ampek Puluh in the mosque area has different criteria from the results of this study. First, Sumbahyang Ampek Puluh in Sijunjung are dominantly followed by women and men only a handful. Even, in certain mosques it is only attended by women besides their imams. Second, the women are generally still very productive because they work in gardens, fields and other places. They make money / materials during the day, cook and prepare food for the family in the afternoon, then they go to the mosque to do religious activities, because this is part of their rights as it is stated by Fauziyah (2010) and Maslikhah (2015). Third, the implementation of Sumbahyang Ampek Puluh activities at the mosque / musalla in the Sijunjung region is not intended by the women to seek protection, both economic protection and family attention because they are not people who do not care for. They are people who have a house, farm / plantation and family members. Their purpose is solely to study for the sake of increasing religious knowledge, getting the perfection of merit and goodness in the month of Ramadan. Therefore, the quality of their humanity is very different from women with different professions, as stated by Supraptiningsih (2016).

\section{CONCLUSION}

Sumbahyang Ampek Puluh is a form of teaching from the Naqsabandiyah Islam that prevails in Sijunjung District with quite a large number of followers in several Mosques and Mushala. This form of worship is carried out for 40 days with a period of 10 days before Ramadan and 30 days during the month of Ramadan. The implementation of this form of worship is carried out both day and night. The main purpose of the implementation is to get closer to Allah and carry out more timely worship. There are several activities carried out during this activity, namely fasting during the day, obligatory praying in congregation and sunnah praying, learning to read and recite the Koran, studying the interpretation of the Koran, and studying religious knowledge. Sumbahyang Ampek Puluh is an effective place to learn, build and strengthen the piety of modern women in the midst of increasingly complex life challenges. Short time (40 days) can improve the quality of knowledge and practice of a Muslim woman for the better. The existence of women in the forty prayers in Sijunjung illustrates the reality of Minangkabau women who are educated, free and free to perform their worship and daily life.

\section{REFERENCE}

Aljunied, K. (2018). Not Just a House to Honour God: Mosques in the Malay World as Cosmopolitan Spaces. Gjat, 8 (1).

Ansor, Muhammad. (2014). Being Woman in the Land of Shari'a Politics of the Female Body, Piety and Resistance in Langsa, Aceh AlJāmi'Ah: Journal of Islamic Studies, Vol. 52, No. 1, pp. 59-83

Ardiyani, Dian. (2017). Konsep Pendidikan Perempuan Siti Walidah, Tajdida, Vol. 15, No. 1

Armiah. (2004). Perilaku Simbolis Santri dalam Praktek Keagamaan di Pesantren Daarut Tauhid Bandung, MediaTor, Vol. 5, No. 2

Beta, Annisa. R. (2016). Socially Mediated Publicness in Networked Society for Indonesian Muslim Women, Jurnal Ilmu Komunikasi, Volume 13 , Nomor 1, 19-30

Fanani, Ahmad Fuad. (2017). The implementation of sharia bylaws and its negative social outcome for Indonesian women, Indonesian Journal of Islam and Muslim Societies, Vol. 7, no.2, pp. 153-174 
Fauziyah, Yayuk. (2010). Ulama Perempuan dan Dekonstruksi Fiqih Patriarkis, Islamica, Vol. 5, No. 1

Hanani, S. (2016). Perlindungan Perempuan Lanjut Usia Korban Bencana Gempa Bumi melalui Tradisi Sumbayang 40 di Sumatera Barat. Kafa'ah: Jurnal Ilmiah Kajian Gender, VI (1).

Harpci, Fatih. (2015). 'Á'isha, Mother Of The Faithful The Prototype of Muslim Women Ulama, Al-Jāmi'ah: Journal of Islamic Studies, Vol. 53, no. 1 , pp. $159-179$

Hidayati, Tatik. (2009). Perempuan Madura antara Tradisi dan Industrialisasi,Karsa, Vol. XVI No. 2

Ibrahim, A. R. (2014). The Apprehensions of Traditional Ulama Towards Women's Participation in Politics in Nigeria. Al-Jāmi'ah: Journal of Islamic Studies, 52 (2), 331-350.

Ismail, N. B. (2017). The Qur'anic Exegesis, Reformism, and Women in Twentieth Century Indonesia. Studia Islamika, 24 (3).

Isnaini, Rohmatun Lukluk. (2016). Ulama Perempuan dan Dedikasinya dalam Pendidikan Islam (Telaah Pemikiran Rahmah El-Yunusiyah), Jurnal Pendidikan Agama Islam Volume 4 Nomor 1

Iwanebel, Fejrian Yazdajird. (2013). Melihat Logika Al-Quran Tentang Perempuan Melalui Terjemah Reformis, Palastren, Vol. 6, No. 2

Jannah, Hasanatul. (2011). Pemberdayaan Perempuan dalam Spiritualitas Islam (Suatu Upaya Menjadikan
Perempuan Produktif), Karsa, Vol. 19 No. 2

Katz, M. H. (2008). Women's Mawlid Performances In Sanaa and the Construction of Popular Islam. Int. J. Middle East Study, 40, 467-484.

Kool, J., Tong, C., \& Turner, B. S. (2008). Women, piety and practice: A study of women and religious practice in Malaysia. Cont Islam, 2, 41-59.

Madya, Efi Brata, Moh. Hatta \& Syukur Kholil. (2017). The Preaching of Sufi in the Batak Land District of Simalungun (A Study of Islamic Communication, Case Study of Tarekat Naqsyabandiyah Serambi Babussalam), IJLRES International Journal on Language, Research and Education Studies ISSN: 2580-6777 (P); 2580-6785 (E) Vol. 1, No. 1

Marhumah. (2015). The roots of gender bias: misogynist hadiths in pesantrens, IJIMS, Indonesian Journal of Islam and Muslim Societies, Volume 5, Number 2, 283-304

Maslikhah, (2015). Pendidikan Islam Berkeadilan Gender: Menyoroti Pemikiran Muhammad Atiyyah alAbrashi, Palastren, Vol. 8, No. 2

Miles, M. B., \& Hubermen, A. M. (1992). Analisis Data Kualitatif. Jakarta: UI Press.

Mukodi \& Afid Burhanuddin. (2015). Domestifikasi Perempuan Samin Dalam Khasanah Masyarakat Islam Modern, Al-Tahrir, Vol. 15, No. 2, $411-430$ 
Munir, (2016). Dinamika Ritual Tarekat Sammâniyah Palembang, Madania Vol. 20, No. 2

Nurwanto. (2012). The portrait of gender justice and injustice in the Islamic teaching textbook and Muhammadiyah teachers' responses, IJIMS, Indonesian Journal of Islam and Muslim Societies, Volume 3, Number 1, 149-173

Rahman, Yusuf. (2017). Feminist Kyai, K.H. Husein Muhammad The Feminist Interpretation on Gendered Verses and the Qur'ānBased Activism, Al-Jāmi'ah: Journal of Islamic Studies, Vol. 55, no. 2, pp.293-326

Rasyidah, Ida \& Noeryamin Aini. (2009). Perempuan dan Ketidakadilan: Review atas Beberapa Isu Gender Menyangkut Dunia Kerja, Studia lslamika. Vol. 16, No. 1

Ridho, Sari Lestari Zainal. (2010). Pendidikan di Negara-Negara Anggota Oki: Perbandingan antara Perempuan dan Laki-Laki Ta'dib, Vol. XV No. 01

Rofhani, (2017). Ekspresi dan Representasi Budaya Perempuan Muslim Kelas Menengah di Surabaya, Islamica: Jurnal Studi Keislaman,Volume 11, Nomor 2

Roza, Ellya \& Yasnel, (2017). Penetrasi Islam dalam Pendidikan Keagamaan Masyarakat Melayu di Rokan Hulu, Potensia: Jurnal Kependidikan Islam, Vol. 3, No. 2

Safitri, D. M. (2010). What Went Wrong with The Veil? A Comparative Analysis of the Discourse of the Veil in France, Iran, and Indonesia. Al-Jami'ah, 48 (1).
Sechzer, J. A. (2004). Islam and Woman: Where Tradition Meets Modernity: History and Interpretations of Islamic Women's Status. Sex Roles, $51(5 / 6)$.

Sila, Muhammad Adlin, (2009). TarekatKadisiyyah: An Example of Neo-TarekatIn Bandung, Indonesia, Al-Jami'Ah, Vol. 47, No. 2

Sulaiman, S., Quayum, M. A., \& Manaf, N. F. (2018). Negotiating Muslim Women's Rights and Identity in American Diaspora Space: An Islamic Feminist Study of Kahf's The Girl in the Tangerine Scarf. Kemanusiaan, 25 (1), 43-67.

Supraptiningsih, Umi. (2016). Karakteristik Pengemis Perempuan Di Kecamatan Tlanakan Kabupaten Pamekasan,Nuansa, Vol. 13 No. 2

Taufiq, Moh. (2017). Pola Pendidikan Berbasis Tareqat Qadiriyah Wan Naqsabandiyah di Pondok Pesantren Assalafi Al-Fitrah Surabaya, Jurnal Pendidikan Agama Islam(Journal of Islamic Education Studies) Volume 5 Nomor 1

Thaib, P. R. (2012). Direktori Minangkabau. Batusangkar: Badan Pekerja Pucuak Adat Alam Minangkabau (BP-PAAM).

Ulfah, Isnatin. (2014). Dari Moderat ke Fundamental: Pergeseran Pemahaman dan Ekspresi Keagamaan Perempuan Nahdlatul Ulama di Ponorogo, Al-Tahrir, Vol. 14, No. 1, 93-115

Umar, M. S. (2007). Gender Issues in Application of Islamic Law in 
Nigeria. Al-Jami'ah, 45 (1).

Wahib, A. B. (2017). Being Pious Among Indonesian Salafis. Al-Jāmi'Ah: Journal Of Islamic Studies, 55 (1), 1-26.

Widiastuti, Novi \& Prita Kartika. (2017). Penerapan Model Kelompok Usaha Kreatif Islami (Kukis) dalam Pemberdayaan Perempuan Berbasis Pondok Pesantren, Jurnal Empowerment Volume 6, Nomor 2

Widiyanto, Asfa. (2014). Salahuddin Wahid and the Defence of Minority Rights in Contemporary Indonesia, Al-Jāmi'ah: Journal of Islamic Studies,Vol. 52, no. 2, pp. 271-307

Widyastuti, Sri Harti. (2014). Kepribadian Wanita Jawa dalam Serat Suluk Residriya dan Serat Wulang Putri Karya Paku Buwono IX, Litera, Volume 13, Nomor 1 